\title{
Group Classification of Killer Yeasts Based on Cross-reactions between Strains of Different Species and Origin
}

\author{
By D. ROGERS* AND E. A. BEVAN \\ Department of Plant Biology and Microbiology, Queen Mary College, \\ University of London, London E1 $4 N S$
}

(Received 14 November 1977)

Strains of killer yeasts of various genera from a variety of sources were tested for their ability to kill each other, two neutral strains and four classes of mutants isolated as being resistant to killer toxin from a stock killer strain $\mathrm{k} 12-1$. The strains tested fell into four groups designated TOX1 to TOX4 according to their killing/immunity reaction with one another and their ability to kill the resistant mutants.

\section{INTRODUCTION}

Killer yeast strains were first reported by Bevan \& Makower (1963) who demonstrated the three phenotypes - killer, neutral and sensitive - with respect to the killer character. Killer strains produce an extracellular toxin which kills sensitive strains (Woods \& Bevan, 1968); neutral strains neither produce toxin nor are they killed by it. Most investigations of the killer character have used laboratory stock strains whose origins are uncertain but may have common parentage. The toxin production and immunity of laboratory stock strains are correlated with the presence of extrachromosomal elements which have been identified as double-stranded RNA viruses (Bevan, Herring \& Mitchell, 1973; Vodkin \& Fink, 1973; Herring \& Bevan, 1974). Since the original discovery, killer yeast strains have been found in Saccharomyces cerevisiae strains isolated outside the laboratory and in other yeast species (Maule \& Thomas, 1973; Naumova \& Naumov, 1973; Imamura, Kawamoto \& Takaoka, 1974; Philliskirk \& Young, 1975; Bussey \& Skipper, 1975). Some of these strains have been shown to differ in their $\mathrm{pH}$ optimum for killing and, in one case, in their immunity to the toxin produced by the laboratory killer strains (Bussey \& Skipper, 1975). Mutants resistant to killing by a laboratory stock killer strain (K12-1) have also been isolated (Al-Aidroos \& Bussey, unpublished). In an analogous situation, mutants resistant to colicins in Escherichia coli were found to be resistant to a limited number of colicinogenic strains and have been used to characterize them (Davies \& Reeves, $1975 a, b)$. Experiments reported here were performed to determine the relationship between killing ability and immunity of as many of these strains as were available.

\section{METHODS}

Strains and growth media. Details of the strains used in this investigation are shown in Table 1. Strains Y1, Y2, X1 and X2, obtained from A. P. Maule (Watney-Mann, Mortlake, London), had been isolated as contaminants of a two-stage continuous beer fermenter on separate occasions. It is possible that they are all derived from a common contaminant strain although this would seem unlikely as they differ in ability to flocculate (A. P. Maule, personal communication). Initially, stable single cell isolates were obtained from each strain.

* Present address: Department of Biological Sciences, McGill University, Montreal, Canada. 
Table 1. Yeast strains tested and their pH optima for killing

\begin{tabular}{|c|c|c|c|c|}
\hline Strain & Species & $\begin{array}{l}\text { Killer } \\
\text { pheno- } \\
\text { type* }\end{array}$ & $\begin{array}{c}\text { pH } \\
\text { optimum } \\
\text { for } \\
\text { killing }\end{array}$ & Reference \\
\hline K4 & Saccharomyces cerevisiae & K & $4 \cdot 7$ & Woods \& Bevan (1968) \\
\hline A364A & S. cerevisiae & $\mathbf{K}$ & $4 \cdot 7$ & $\begin{array}{l}\text { Fink \& Styles (1972), } \\
\text { Wickner (1974) }\end{array}$ \\
\hline NCYC 232 & S. cerevisiae & $\mathbf{K}$ & $4 \cdot 7$ & Philliskirk \& Young (1975) \\
\hline Y1 & S. cerevisiae & $\mathrm{K}$ & $4 \cdot 2$ & Maule \& Thomas (1973) \\
\hline Y2 & S. cerevisiae & $\mathbf{K}$ & $4 \cdot 2$ & Maule \& Thomas (1973) \\
\hline $\mathrm{x} 1$ & S. cerevisiae & $\mathbf{K}$ & $4 \cdot 2$ & Maule \& Thomas (1973) \\
\hline$x^{2}$ & S. cerevisiae & $\mathbf{K}$ & $4 \cdot 2$ & Maule \& Thomas (1973) \\
\hline M437 & S. cerevisiae & $\mathrm{K}$ & $4 \cdot 2$ & Naumova \& Naumov (1973) \\
\hline ATCC 15126 & Torulopsis glabrata & $\mathbf{K}$ & $4 \cdot 0$ & Bussey \& Skipper (1975) \\
\hline NCYC 575 & Saccharomyces drosophilarum & $\mathbf{K}$ & $4 \cdot 1$ & Philliskirk \& Young (1975) \\
\hline 61 & Candida albicans & $\mathrm{K}$ & $4 \cdot 7$ & Mitchell (1974) \\
\hline 68 & C. albicans & $\mathrm{K}$ & $4 \cdot 7$ & Mitchell (1974) \\
\hline $\mathrm{N} 1$ & S. cerevisiae & $\mathbf{N}$ & - & Somers \& Bevan (1969) \\
\hline NCYC 482 & S. cerevisiae & $\mathbf{N}$ & 一 & Maule \& Thomas (1973) \\
\hline
\end{tabular}

${ }^{*} \mathrm{~K}$, Killer; $\mathrm{N}$, neutral.

Complete liquid medium contained $1 \%(\mathrm{w} / \mathrm{v})$ yeast extract (Difco), $1 \%(\mathrm{w} / \mathrm{v})$ Bacto-peptone (Difco) and $2 \%(\mathrm{w} / \mathrm{v})$ glucose. Methylene blue agar medium contained, in addition, $1.5 \%(\mathrm{w} / \mathrm{v})$ agar and $0.003 \%$ $(\mathrm{w} / \mathrm{v})$ methylene blue, and was buffered to the required $\mathrm{pH}$ with $0.05 \mathrm{M}$-citrate/phosphate (CP) buffer. The agar was autoclaved separately from the other constituents of the medium to prevent hydrolysis.

Determination of the killer phenotype. The killer phenotype was determined using the methylene blue agar technique (Somers \& Bevan, 1969). The sensitive phenotype was determined only as a background lawn to avoid the problem of blue mutants which are indistinguishable from sensitive strains when streaked on to a killer background (Mitchell \& Bevan, 1973).

Determination of the resistant phenotype. The phenotype of the resistant mutants with respect to the various killer strains was determined using crude cell-free toxin preparations in the Well test (Woods \& Bevan, 1968). Cells were grown to late-exponential phase $\left(5 \times 10^{7}\right.$ to $7 \times 10^{7}$ cells $\left.\mathrm{ml}^{-1}\right)$ at $23^{\circ} \mathrm{C}$ in liquid complete medium buffered to the required $\mathrm{pH}$ with $\mathrm{CP}$ buffer. The cells were removed by pressure filtration through glass-fibre filters (Whatman GF/A) and cellulose acetate filters (Millipore, $0.45 \mu \mathrm{m}$ pore size) and concentrated 20-fold by ultrafiltration through an Amicon PM10 membrane in an Amicon model 52 cell [Jencons (Scientific) Ltd, Hemel Hempstead, Hertfordshire] at $4{ }^{\circ} \mathrm{C}$. The resistant strains under investigation were seeded at $5 \times 10^{4}$ cells $\mathrm{ml}^{-1}$ in complete medium with $1 \%$ agar and buffered to the $\mathrm{pH}$ optimum of the killer toxin under investigation with CP buffer.

\section{RESULTS AND DISCUSSION}

All the strains under investigation were tested for differences in both their killing and immunity cross-reactions. These differences reflect differences in both the killer toxins produced and the immunity system. The information so gained permits the grouping of strains giving the same pattern of cross-reactions.

Initial experiments were performed using the methylene blue agar technique to determine the ability of various strains to kill seven stock sensitive strains on media buffered at various $\mathrm{pH}$ values from $4 \cdot 0$ to $5 \cdot 0$. All the strains killed all seven sensitive strains but only over a narrow $\mathrm{pH}$ range. All killer strains were tested for their ability to kill each other over a range of $\mathrm{pH}$ values from 4.0 to 5.0 to determine the killer phenotype with respect to each other and the effect of $\mathrm{pH}$ on the immune reaction. Strain $\mathrm{N} 1$, which is neutral to the laboratory killer strains (Somers \& Bevan, 1969), and strain NCYC 482, which is neutral to the brewery strains, were also included in these tests. The results are given in Table 2.

None of the strains tested which were resistant to a toxin at its $\mathrm{pH}$ optimum were sensitive to the toxin outside the narrow $\mathrm{pH}$ band for optimum stability. The immunity 
Table 2. The killing/immunity reactions of killer and neutral yeast strains

Strains were tested for sensitivity to toxin by spreading them as a background lawn on methylene blue agar and streaking the killer strain on to the lawn.

Background lawn

\begin{tabular}{|c|c|c|c|c|c|c|c|c|c|c|c|c|c|c|}
\hline $\begin{array}{l}\text { Killer } \\
\text { streak }\end{array}$ & K4 & A364A & $\begin{array}{c}\text { NCYC } \\
232\end{array}$ & 61 & 68 & Y1 & $\mathrm{Y} 2$ & $\mathrm{x} 1$ & $x 2$ & M437 & $\begin{array}{l}\text { ATCC } \\
15126\end{array}$ & $\begin{array}{c}\text { NCYC } \\
575\end{array}$ & N1 & $\begin{array}{c}\text { NCYC } \\
482\end{array}$ \\
\hline K4 & - & - & - & - & - & $\mathrm{x}$ & $\mathrm{x}$ & $\mathrm{x}$ & $x$ & $\mathrm{x}$ & $x$ & $x$ & - & $x$ \\
\hline A364A & - & - & - & - & - & $\mathrm{X}$ & $\mathrm{x}$ & $x$ & $x$ & $\mathrm{x}$ & $\mathrm{x}$ & $\mathrm{x}$ & - & $\mathrm{x}$ \\
\hline NCYC 232 & - & - & - & - & - & $\mathrm{x}$ & $\mathrm{x}$ & $\mathrm{x}$ & $\mathrm{x}$ & $x$ & $x$ & $x$ & - & $\mathrm{x}$ \\
\hline 61 & - & - & - & - & - & $x$ & $\mathrm{x}$ & $\mathrm{X}$ & $x$ & $x$ & $x$ & $x$ & - & $x$ \\
\hline 68 & - & - & - & - & - & $\mathrm{x}$ & $\mathrm{x}$ & $\mathrm{x}$ & $\mathrm{x}$ & $x$ & $x$ & $x$ & - & $x$ \\
\hline $\mathbf{Y 1}$ & $\mathrm{x}$ & $x$ & $x$ & $x$ & $x$ & - & - & - & - & - & $x$ & $x$ & $x$ & - \\
\hline Y2 & $x$ & $x$ & $\mathrm{x}$ & $x$ & $x$ & - & - & - & - & - & $x$ & $\mathrm{x}$ & $\mathrm{x}$ & - \\
\hline $\mathrm{x} 1$ & $\mathrm{x}$ & $x$ & $x$ & $\mathrm{x}$ & $x$ & - & - & - & - & - & $\mathrm{x}$ & $x$ & $\mathrm{x}$ & - \\
\hline $\mathrm{x} 2$ & $x$ & $x$ & $x$ & $x$ & $x$ & - & - & - & - & - & $x$ & $x$ & $\mathrm{x}$ & - \\
\hline M437 & $\mathrm{x}$ & $\mathrm{x}$ & $x$ & $\mathrm{X}$ & $x$ & - & - & - & - & - & $x$ & $\mathrm{x}$ & $\mathrm{x}$ & - \\
\hline $\begin{array}{l}\text { ATCC } \\
15126\end{array}$ & $x$ & $\mathrm{x}$ & $x$ & $x$ & $\mathrm{x}$ & $x$ & $\mathrm{x}$ & $\mathrm{x}$ & $x$ & $x$ & - & $x$ & $\mathrm{x}$ & $\mathrm{x}$ \\
\hline NCYC 575 & $x$ & $x$ & $x$ & $\mathrm{x}$ & $\mathrm{x}$ & $x$ & $\mathrm{x}$ & $x$ & $x$ & $\mathrm{x}$ & $\mathrm{x}$ & - & $x$ & $x$ \\
\hline
\end{tabular}

Table 3. The immunity of resistant mutants to toxins produced by various killer yeast strains

The resistant mutants were seeded at $5 \times 10^{4}$ cells $\mathrm{ml}^{-1}$ and tested for their resistance to crude cell-free toxin solution using the Well test.

\begin{tabular}{|c|c|c|c|c|c|c|c|}
\hline \multirow[b]{2}{*}{$\begin{array}{l}\text { Strain from which } \\
\text { toxin was isolated }\end{array}$} & \multicolumn{7}{|c|}{ Resistant mutant (seeded strain) } \\
\hline & $\begin{array}{l}\mathrm{s} 14.67 \\
\mathrm{Kre}_{1}\end{array}$ & $\begin{array}{l}\mathrm{s} 14.96 \\
\mathrm{Kre}_{1}\end{array}$ & $\begin{array}{l}\text { s30.15 } \\
\text { Kre }_{1}\end{array}$ & $\begin{array}{c}\mathrm{s} 14.14 \\
\mathrm{Kre}_{2}\end{array}$ & $\begin{array}{c}\mathrm{s} 14.44 \\
\mathrm{Kre}_{3}\end{array}$ & $\begin{array}{l}\mathrm{s} 14.26 \\
\mathrm{Kre}_{3}\end{array}$ & $\begin{array}{l}\mathrm{MB}^{\mathrm{M} 6} \\
\mathrm{Kre}_{4}\end{array}$ \\
\hline K4 & - & - & - & - & - & - & _ \\
\hline A364A & - & - & - & - & - & - & - \\
\hline NCYC 232 & - & - & - & - & _- & - & - \\
\hline 61 & - & - & - & - & - & - & - \\
\hline 68 & - & - & - & - & - & - & - \\
\hline Y1 & - & - & - & $\mathrm{x}$ & $\mathrm{x}$ & $\mathrm{x}$ & $\mathrm{x}$ \\
\hline M437 & - & - & - & $\mathrm{x}$ & $\mathrm{x}$ & $\mathrm{x}$ & $\mathrm{x}$ \\
\hline ATCC 15126 & - & - & - & $\mathrm{x}$ & $\mathrm{x}$ & $\mathrm{x}$ & - \\
\hline NCYC 575 & - & - & - & $\mathrm{x}$ & - & - & - \\
\hline
\end{tabular}

-, Mutant resistant to toxin; $x$, mutant sensitive to toxin.

of the strains did not therefore appear to be dependent upon the $\mathrm{pH}$ of the medium although the toxins themselves may be rapidly inactivated outside a narrow $\mathrm{pH}$ band (Woods \& Bevan, 1968; Bussey, 1972; Philliskirk \& Young, 1975).

Crude cell-free toxin solutions from the various killer strains were tested against mutants isolated as resistant to killer toxin from laboratory strains using the Well test. A zone diameter consistent with less than $5 \%$ of the killing found with a stock sensitive strain was considered a resistant phenotype. The results are given in Table 3.

The strains investigated fell into four groups with respect to their killing and immunity cross-reactions (Table 2). The reactions of the mutants resistant to the toxins showed the same pattern (Table 3). In view of these results, and those of experiments reported elsewhere which showed physicochemical differences between the toxins produced by different killer strains (Bussey \& Skipper, 1975; Philliskirk \& Young, 1975; Rogers, 1976), one can conclude that the difference in cross-reaction patterns of the strains in each group is due to the production of different killer toxins and immunity systems. Thus it is suggested that the strains are classified in the following manner: (i) TOX1 strains - the laboratory 
stock strains, Candida albicans strains 61 and 68, strain NCYC 232 and the neutral strain $\mathrm{N} 1$; (ii) TOX2 strains - the brewery strains $\mathrm{Y} 1, \mathrm{Y} 2$, $\mathrm{X} 1$ and $\mathrm{X} 2$, the Russian wine fermentation strain M437 and the neutral strain NCYC 482; (iii) TOX3 strains - Torulopsis glabrata strain ATCC 15126; (iv) TOX4 strains - Saccharomyces drosophilarum strain NCYC 575. The resistant mutants show different patterns of resistance to strains within these four groups: $\mathrm{Kre}_{1}$ mutants are resistant to toxins from strains of all four groups; $\mathrm{Kre}_{2}$ mutants are resistant to toxins from TOX1 strains but are -sensitive to all other toxins; $\mathrm{Kre}_{3}$ mutants are resistant to toxin from TOX1 and TOX4 strains but are sensitive to toxin from strains in groups TOX2 and TOX3; and $\mathrm{Kre}_{4}$ mutants are resistant to all toxins except those produced by TOX 2 strains.

A complete analysis of all known killer strains would no doubt reveal further groups in addition to the four described. Similarly, a search for killer and neutral yeast strains amongst stock cultures may reveal further groups.

The results of the experiments with the resistant mutants suggest each of the toxins has both unique and common sites of attachment or attack on sensitive cells. The killer system in yeast shows many similarities to the colicinogenic system of Escherichia coli. The results reported here add further to these similarities, showing different cross-reacting groups as in E. coli (Fredericq, 1956; Fields \& Luria, 1969a,b) and resistant mutants (Davies \& Reeves, $1975 a, b$ ).

\section{REFERENCES}

Bevan, E. A. \& Makower, M. (1963). The physiological basis of the killer character in yeast. Proceedings of the 11th International Conference on Genetics 1, 203. (Abstract)

Bevan, E. A., Herring, A. J. \& Mitchell, D. J. (1973). Two species of dsRNA in yeast: their preliminary characterisation and relationship to the killer character. Nature, London 245, 81-86.

BUSSEY, H. (1972). Effects of yeast killer factor on sensitive cells. Nature New Biology 235, 73-75.

BusSEY, H. \& SKIPPER, N. (1975). Membranemediated killing of Saccharomyces cerevisiae by glycoproteins from Torulopsis glabrata. Journal of Bacteriology 124, 476-483.

DAvies, J. K. \& ReEves, P. (1975a). Genetics of resistance to colicins in Escherichia coli $\mathrm{K} 12$ : cross resistance among colicins of group $\mathbf{B}$. Journal of Bacteriology 123, 96-101.

Davies, J. K. \& ReEves, P. (1975 b). Genetics of resistance to colicins in Escherichia coli $\mathrm{K} 12$ : cross resistance among colicins of group A. Journal of Bacteriology 123, 102-117.

FieldS, K. L. \& LuRIA, S. E. (1969a). Effects of colicins $\mathrm{E} 1$ and $\mathrm{K}$ on transport systems. Journal of Bacteriology 97, 53-63.

Fields, K. L. \& LuRIA, S. E. (1969 b). Effects of colicin E1 and $\mathrm{K}$ on cellular metabolism. Journal of Bacteriology 97, 64-77.

Fink, G. R. \& Styles, C. A. (1972). Curing of a killer factor of Saccharomyces cerevisiae. Proceedings of the National Academy of Sciences of the United States of America 69, 2846-2849.

FrederiCQ, P. (1956). Resistance et immunité aux colicine. Comptes rendus des séances de la Société de Biologie 150, 1514-1517.

Herring, A. J. \& Bevan, E. A. (1974). Virus-like particles associated with the dsRNA species found in killer and sensitive strains of the yeast Saccharomyces cerevisiae. Journal of General Virology 22, 387-394.
Imamura, T., KaWamoto, M. \& TAKaOKA, Y. (1974). Isolation and characteristics of killer resistant mutants of Saké yeast. Journal of Fermentation Technology 52, 300-305.

Maule, A. P. \& Thomas, P. D. (1973). Strains of yeast lethal to brewery yeast. Journal of the Institute of Brewing 79, 137-141.

Mitchell, D. J. (1974). The correlation between nucleic acid differences and the killer phenotypes of yeast. Ph.D. thesis, University of London.

Mitchell, I. DE G. \& Bevan, E. A. (1973). Definition of blue mutant phenotype and its genetic basis in Saccharomyces cerevisiae. Genetical Research, Cambridge 22, 169-179.

Naumova, T. I. \& Naumov, G. I. (1973). The comparative genetics of yeast. XII. Study of antagonistic inter-relations in Saccharomyces. Genetika 9, 85-90.

Philliskirk, G. \& Young, T. W. Z. (1975). The occurrence of killer character in yeasts of various genera. Antonie van Leeuwenhoek 41, 147-151.

RoGERS, D. (1976). The genetic and phenotypic characterization of killer strains of yeast isolated from different sources. Ph.D. thesis, University of London.

Somers, J. M. \& Bevan, E. A. (1969). The inheritance of the killer character in yeast. Genetical Research, Cambridge 13, 71-83.

Vodkin, M. H. \& Fink, G. R. (1973). A nucleic acid associated with a killer strain of yeast. Proceedings of the National Academy of Sciences of the United States of America 70, 1069-1072.

WICKNER, R. B. (1974). Chromosomal and nonchromosomal mutations affecting the 'killer character' of Saccharomyces cerevisiae. Genetics 76, 423-432.

Woods, D. R. \& Bevan, E. A. (1968). Studies on the nature of the killer factor produced by Saccharomyces cerevisiae. Journal of General Microbiology 51, 115-126. 